\title{
Creationism and the Teaching of Evolution in Poland
}

\author{
Bartosz Borczyk
}

Published online: 23 October 2010

(C) The Author(s) 2010. This article is published with open access at Springerlink.com

\begin{abstract}
For many years, the creationist movement in Poland was so marginal that the term "creationism" and its foundations were largely unknown within society. Nevertheless, at the end of the 1980s and beginning of the 1990s, the country underwent rapid political, economic, and sociological transformation. As part of the reaction, many ideas previously censored by the Communist regime became fashionable. This was also partly true for the creationist movement. However, creationism did not gain high acceptance within society, partly because Poland is predominantly a Catholic country, and Catholic doctrine does not support literal understanding of the Bible. At the moment, Intelligent Design creationists are emerging in Poland, and numerous creationist organizations are increasing their activity. This goes together with the weakening of evolutionary teaching in Polish schools.
\end{abstract}

Keywords Creationism · Education · Evolution · Intelligent design · Poland

\section{Introduction}

The ideas of common ancestry and natural selection were expressed roughly 150 years ago by Alfred Russel Wallace and Charles Darwin. Soon, given the growing body of evidence, the theory of evolution was widely accepted by naturalists and became a fundamental issue of modern biology. It was also considered among the greatest achieve-

\footnotetext{
B. Borczyk $(\bowtie)$

Laboratory of Vertebrate Biology and Conservation,

Institute of Zoology, University of Wroclaw,

Sienkiewicza Street 21,

50-553 Wrocław, Poland

e-mail: borczyk@biol.uni.wroc.pl
}

ments of Western thought, together with ideas such as the Copernican revolution and Newton's mechanics (e.g., Dennett 1996). However the idea of evolution contradicts many religious beliefs and thus generates conflicts with religious fundamentalists who advocate for literal understanding of the Biblical story of creation (in the case of Christian fundamentalists; other religions have other creation stories). The history of the conflict between creationists and scientists is very well documented (e.g., Numbers 2006; Matzke 2010).

Strong opposition to evolution was typically linked with the southern region of the United States often called "the Bible belt." However, during the last ten to twenty years, creationism movements have been spreading around the world, and more and more countries are becoming infected by this intellectual plague (Numbers 2006). This raises a serious threat to education, public understanding of science, and in the wider perspective, society and democracy, since many of the leading creationists (or their patrons) are deeply involved in politics (see Forrest and Gross 2007a, b).

The intent of this paper is to describe the recent rise in activity of the creationist movement in Poland - a mostly Catholic country. The development of the creationist movement in Poland is placed in the context of political and social change during the early 1990s.

\section{Creationism in Poland Before 1990}

After World War II, there was no serious creationist movement in Poland for several reasons. First, the isolation of Eastern Block countries from the "evil" Western world prevented the country from importing the idea of creationism. Second, as in the former Eastern Germany, solid science education served as part of the ideological struggle 
against the capitalistic world (see Kutschera 2008). Third, at least for some time, there was ideological pressure and censorship that used science (including evolution) as a propaganda tool (the most striking example is "creative Darwinism" and Lysenkian ideologies developed to support communist philosophy; Łomnicki 1994; Kuźnicki 2009). Finally, facing serious economical problems and rebuilding the country after the World War II, people were more engaged in everyday life and the struggle for freedom than in thinking about Biblical creation versus evolutionary contradictions. Thus, there was no background for creationism to arise.

In Polish textbooks or popular publications about evolution written by Polish authors before 1990, information about creationism is lacking or very marginal, presented in a historical context (the pre-Darwinian view on life and sociological effect of publication of $O n$ the Origin of Species; e.g., Kuźnicki and Urbanek 1967). This is also true for most textbooks published after 1990; but in some popular books, many authors noticed the problem and clarified some misconceptions.

Still, in the 1980 s, slightly more vigorous creationist activity appeared in Poland. Most of the advocates were Jehovah's Witnesses who published Polish translations of several papers and books (e.g., Watchtower 1989). But the impact of their activity was rather marginal.

\section{Creationism in Poland After 1990}

The end of the 1980s and beginning of the 1990s was a time of great political change in Middle and Eastern Europe. The landmarks of the era are Lech Wałęsa and Solidarność in Poland, the fall of the Berlin Wall in Germany, and the "Velvet Revolution" in former Czechoslovakia. It was a time of political transformation from communism to democracy, which resulted in changes to several aspects of life, such as the end of censorship, the possibility of traveling around the world without restriction (which was not possible before), the free market, and many other changes. One of the sociological aspects was shortlived, exaggerated attitudes toward almost anything called "western," especially anything coming from the U.S.

Political transformations after 1990 opened the way for the Catholic church to enter the schools (Catholic religion is taught in public schools in Poland, although it is not obligatory; for discussion of the relation of the Catholic church to creationism, see below). The early start of religious indoctrination, in contrast to science education, may at least be potentially responsible for the growing number of creationists (e.g., Kutschera 2008). The second reason may be the free flow of ideas (including creationist activity). Recent polls on public acceptance of evolution in
34 countries including Poland show that almost 30 percent of citizens do not accept this idea (Miller et al. 2006). Creationist activity in 2006 inspired another poll of evolution acceptance, which showed patterns similar to those mentioned above (TNS 2006). However, the acceptance of evolution was higher among younger and better educated respondents versus older groups and those without higher education.

In 1993, the Polish Anti-Macroevolution Organization was established, then officially registered in 1995. It gathers all kinds of creationists, including young-earth creationists, devolutionists, and intelligent design (ID) creationists. The association published a bimonthly journal ("Na Poczatku" (At the Beginning), now renamed Aspekty Genezy (Aspects of Genesis), and from time to time, separate compilations of selected articles from the journal. They have published several books, including Anckberg and Weldon (2003), Pajewski (1992) Creation or Evolution, largely based on Morris and Parker's book What is creation science? (both of them young-earth creationist), and Moczydłowski (1994), God or Natural Selection, a compilation of essays published in the popular press by both evolutionists (A. Urbanek, K. Sabath, A. Joahimiak, A. Paszewski) and creationists (M. Giertych and E. Moczydłowski). It is worth mentioning that Moczydłowski reprinted some of the evolutionists' articles without getting copyrights from either the author (in this case Karol Sabath) or the publisher Kosmos, a Polish-language biology journal; Kosmos 1993; Sabath 1993). Contradictions among them, as much or even more than evolution itself, seem meaningless to creationists. Clearly, their unifying idea is the hatred of evolution. For example, ID architects from the Discovery Institute try to distance themselves from young-earth creationism (West 2002), but at the same time the latter welcome ID as a useful tool against evolution (e.g. Cuberbiller 2007). The catastrophists need several episodes of creation following the catastrophes that destroyed former worlds, but other creationist tribes need only one event of creation. Also, young-earth creationists often cite devolutionists (who state that a reduction in genetic diversity is being documented, which is opposed to their view of what evolution is), as an argument against evolution's accounting for the diversity of life. However, by presenting such an opinion, they cut off the possibility that Noah took just "created kinds" of animals to the Ark that later evolved within the "kinds," a well-known tactic used to reduce the number of animals required on board the ark with Noah. If they do not invoke devolution and argue for "evolution within created kinds" after "the global flood," starting from single pairs of animals to their recent diversification, as well as within the past 10,000 years, they became the most radical evolutionists ever to exist. Curiously, sometimes they even use all the arguments mentioned above in different parts of 
the same paper, as Wieland (2000) did! (Polish supporters of both devolution and flood geology are Giertych (2008) and Maryniarczyk (2008), for example. See also Pigliucci (2002) for discussion of mutual contradictions among creationists.

The second creationist society active in Poland is the Biblical Creationist Society (registered in 2004), which groups only young-earth creationists; and moreover, their members must be evangelical Christians. They regularly organize workshops for schoolteachers, lectures by leading young-earth creationists (like Sylvia Baker and Paul Garner, among others), and promote their ideas via Internet websites. They also organize Polish showings of the pro-ID movie "Expelled: No Intelligence Allowed" (this movie is available on YouTube.com with Polish subtitles). It is also possible to buy a Polish-version DVD of another pro-ID production "The Mystery of Life's Origin" and Phillip Johnson's book (Defeating Darwinism by Opening Minds) via their web page (www.inteligentny-projekt.pl; the "inteligentny-projekt" in the web page address translates as "intelligent-design"). There are also links to a free antievolutionary video, "Evolution-Facts or Beliefs" (with Polish dubbing) available on the website. It is further worth mentioning in passing that the Polish Biblical Creationist Society is allied with the young-earth creationists who also support the ID movement. Clearly, there is nothing more going on within the different creationist movements beyond their joint hatred toward evolution overall. Another active group is the young-earth creationist Church of the New Testament from Lublin. In most cases, the motivation of these groups is clearly religious, backed up by the most primitive sorts of anti-evolution arguments. Their activity does not attract serious public attention, but their outreach and energy may change this situation in the near future.

\section{The Anti-Evolution Campaign of Maciej Giertych}

There were two major events concerning creationism in Poland in recent years that aroused some serious interest. Both of them were inspired by Maciej Giertych, a politician who holds a Ph.D. in plant physiology (Łomnicki 1994; Kutschera 2006a, b). During the early 1990s, Giertych sent a free videotape entitled "Evolution: Fact or Belief" to many Polish schools and started a brief public debate, mainly in the Catholic press. Moreover, one Catholic newspaper published false information that the Ministry of Education recommended the videotape. This led the Ministry to prepare a special book clarifying the misleading information presented in the videotape (Lomnicki 1994). At the time, Giertych was also strongly involved in promoting a Polish edition of a particularly weak creationist book, The Crumbling Theory of Evolution (Johnson 1989).
Giertych's launched his next attack on evolution in 2006, following a debate he organized in the European Parliament (covered in Graebsch 2006; Kutschera 2006a, b; and others). His ideas are mostly considered ridiculous at the least (see his argument for coexistence of dinosaurs and humans deduced from folk stories such as the Loch Ness monster in Giertych 2006). Such activity always provokes vigorous response from Polish scientists (for example Sabath 1990, 1993; Łomnicki 1994; Graebsch 2006); however, the false impression that "something is wrong with evolution" and that there are "serious controversies among scientists about evolution" is planted in people's minds. This is exactly what Forrest and Gross (2007a) emphasized: that a rather small number of highly motivated creationists can create a real mess. It is also worth mentioning that, although political candidates' views on the evolution-creationism conflict is not a campaign issue (see Miller et al. 2006 for discussion of the differences between U.S. and European countries), this topic may emerge in politics, on even as high a level as the Ministry of Education.

Giertych's anti-evolution campaign in 2006 gained strong support from vice-minister of Education Mirosław Orzechowski, who claimed in an interview for a popular newspaper, that evolution is a lie and also the concept of an old, faithless man (Charles Darwin) who had probably lost his inner fire because he was a vegetarian (Pezda 2006; the Minister of Education at the time was Roman Giertych, son of Maciej). In reaction to this, several open letters signed by prominent scientists, the Senate of the University of Warsaw, and even some Catholic church hierarchs, were published to manifest the disagreement with such a statement (Nauka 2006). In addition, more than a thousand Polish scientists signed an open letter addressed to the Prime Minister demanding that Mirosław Orzechowski be dismissed (Gazeta Wyborcza 2006); however, the letter was ignored.

One of the sad but significant effects of the creationist campaign started by Giertych appeared in one of the public schools in Łódź (one of the largest cities in Poland), where the school's headmaster refused to present a poster about human evolution in a biology classroom, arguing that "evolution is only a theory, and scientists still are not sure about it" (Markowski 2006). Alas, this claim elicited no serious reaction from the local school superintendent. However, one positive note in the whole situation is that this was among a handful of individual cases, and some serious interest arose amongst the most popular and opinion-making presses, who called the situation grotesque and stupid.

The newest rise of Giertych's activity dates to November 2009. He announced a debate entitled "Darwin's Year-A Debate: Devolution contra Evolution. Giertych contra Darwin" 
(Polish Anti-Macroevolution 2009). The announcement suggested that the host of the debate was the Biology Division of the University of Warsaw. Just after this announcement appeared, Professor Zofia Kielan-Jaworowska (2009) published an open letter addressed to the dean of the Biology Division warning against potential damage to public understanding of science if a creationist meeting were held at a major Polish university. However, Giertych did not rent the lecture hall directly. The organizer was a private business office, which promised the dean quite a different event. The day after professor Kielan-Jaworowska published her letter, the Biology Division published laconic information on their official web site that the division would not host the debate and would not make any of their halls available for such an activity. In response, the Polish Anti-Macroevolution Society published an angry note suggesting that declining to host a creationist event at the University of Warsaw is an example of censorship, that scientists are afraid of the truth, and that evolution is used to being "defended using methods from the age of Lysenko" (Ostrowski 2009).

\section{The Intelligent Design Movement in Poland}

At the moment, ID is wedging its way into Poland. There are several books translated into Polish, including Behe's (2008) Darwin's Black Box, Wells' (2007) Icons of the Evolution, Johnson's (1997, 2007) Darwin on Trial and Defeating Evolution by Opening Minds, Strobel's (2007) The case for a Creator, Intelligent Design 101 (House 2009), and Science versus Religion (Fuller 2010), among many others. Unfortunately, ID creationism is supported indirectly-but nonetheless supported-by some philosophers like Bylica (2003), Sagan (2004, 2008), and Jodkowski (2007), who claim that this discipline is scientific, although they do not aspire to judge the superiority between ID and evolution and try, at least officially, to be neutral. They started an online journal, "Filozoficzne Aspekty Genezy" ("The Philosophical Aspects of Genesis"), and a book series, entitled Biblioteka Filozoficznych Aspektów Genezy (The Library of Philosophical Aspects of Genesis), published by Megas Press, whose owner is Eugeniusz Moczydłowski, a chairman of the Polish Anti-Macroevolution Organization. Some of the items from the book series enjoy financial support from the University of Zielona Góra (Bylica, Jodkowski, and Sagan employer), which is a public, not a private, university. The group led by Jodkowski publishes several translations of books, book chapters, papers, and original papers that support or are critiques of ID (see www.nauka-a-religia.uz.zgora.pl). Yet recent claims by Jodkowski (2007) are that ID is a fully fledged research program, which should not be viewed as creationism, and Sagan finds that ID provides better explanations of some biological phenomena, opposed to the theory of evolution (Sagan 2008, 2009). Such activity is an unnecessary and unjustified legitimization of ID creationism.

The popular press very rarely writes about ID. In most cases, the articles are highly critical of the movement (e.g., Gadziński 2006; Olender 2006), and the authors correctly recognize close connections between ID and religious movements, with the exception of a few articles from religious journals (e.g., Stelmach 2006). Still, the number of popular articles, books, talks, and websites dedicated to different kinds of creationism is constantly increasing.

\section{The Catholic Church and Creationism in Poland}

According to official statements, more than 95 percent of the Polish population is Roman Catholic, with approximately 58 percent of practicing Catholics, taking an active part in everyday church life (Okrój 2006). Although the idea of evolution generally holds serious implications for all belief systems, the Polish Catholic Church is not seriously interested in evolution.

Official statements may be summarized as agreement with biological evolution, while "special creation" is restricted to the episode of bestowing a soul upon humankind. The Church also stresses that evolution, as biologists see the process, might be the way God created life on Earth (e.g., Życiński 2002). They mainly conform to the famous statement of Pope John Paul the Second (born in Poland and still very popular). But it's not hard to find more radical views on evolution among Catholics officials, and at least two mainstream creationism trends, young-earth and Intelligent Design creationism, have their prominent representatives. Recently, the Catholic University of Lublin released a post-conference book, entitled Ewolucjonizm czy Kreacjonizm (Evolutionism or Creationism), with most of the papers being critical of evolution (Jaroszyński et al. 2008). Surprisingly, the book was financially supported by the Ministry of Science and Higher Education!

As mentioned before, Catholic religion is taught at school (those classes are named "Religion" without specifying the belief, suggesting we have just one). Although it is not obligatory-one can choose an Ethic as an alternative-there is no real freedom of choice, especially in smaller towns (the problem recently being raised at the Strasbourg Tribunal). A recent report on religion classes in Polish schools reveals that there are teachers (not all) who still teach the literal interpretation of Genesis, in spite of the official Vatican statement (Podgórska 2008). Obviously, such a situation may create serious problems for children, who are taught during science classes that the Earth is very old and that evolution is well established, while their next class must acclaim the six-day creation and 
the Noah flood legend as truth (Podgórska 2008). In effect, what is taught is neither "religion" nor biology, but conformism.

With regard to evolution versus creationism, the Catholic church seems highly flexible (Tyrała 2007). Both mainstream acceptance of biological evolution and niches for more radical views on the evolution-creation controversy may be viewed as a kind of marketing tool to keep as many believers close to the Church as possible.

\section{Evolution Education}

After World War II, communist regimes strongly influenced scientific society, using it as a propaganda tool. This was specially true for biologists, who were forced (at least officially) to accept Lysenko's ideology and "creative Darwinism" (Kuźnicki 2009). This was the reason that for some years after rejection of Lysenko's theories, evolution was in fact connected to his ideas and thus marginalized (Lomnicki 1994). The situation has been changing slowly, and as mentioned above, evolution education has gained a better standard. However, the rise of creationist activity has led to a few attempts to remove evolution from the school syllabus (see Giertych's activity described above). Most of them to little effect.

Due to the order of the Polish school syllabus, evolution is the last topic taught during the school year. As a result, two phenomena arise which perhaps may surprise a foreign educator. First, at the end of the school year (which starts in Poland on September first and finishes around June 20th), teenagers' minds are already on the holidays. Having already earned their final grades, students do not pay serious attention to the curriculum (that is true for all subjects: mathematics, chemistry, etc.). Secondly, one or more of the previous lessons is often cancelled; or due to other events, all teaching schedules are delayed by one or two weeks (this is not the rule, but as far as I hear from teachers, nothing has changed since I was a student). Consequently, evolution, the last topic on the schedule, is drastically shortened because presenting it in whole would overlap the holidays (this is not a problem of evolution itself, but happens to all topics put at the end of the school syllabus: biology, chemistry, physics, mathematics, geography, etc.).

In the past few years, there has been ongoing reformation of the public education system in Poland. In a recent draft of the proposed school curriculum, evolution has been shifted to the earlier stage of education (gymnasium) and reduced in its scope (www.edu.gov.pl). On the one hand, I view this move as a good idea because it allows children to learn the concepts earlier, but the course must be repeated and expanded in the next level of education-lyceum. But this is not now the case. In the prepared curriculum, evolution is not included as a separate topic in the basic path. It is quite well described in the expanded profile. The result is that most lyceum graduates, aged 18 , had their last contact with the theory of evolution in gymnasium at the age of 14. Surely this will lead to a serious decrease in the public understanding of evolution and will have a negative impact on the future scientific potential of Poland (see also Miller [2008] discussion of the risks of weak science education).

\section{Possible Future}

My opinion is based on several talks with other biologists, who are generally convinced that creationism will not spread in Poland, so preventive activity is unnecessary. Such optimism is, in my opinion, unjustified. Although creationists are not (usually) as visible here as they are, for example, in the U.S., they do constitute about 30 percent of our society. Worldwide, creationists are much better organized and clearly focused on the social mind, not on science debates (see Forrest and Gross 2007b). We, being scientists, are so often in the habit of ignoring the problem. Our reaction is based on the fact that we look for a clear argument, quality data, and falsifiable theories, while creationist concepts simply do not meet these standards. One can say, "their evidence is so poor that there is no way to convince either me or any other person of an average intelligence, thus it is not worthy of our interest." But such a statement is wrong. The "person of average intelligence" does not know much about science philosophy and methodology; for many of them, evolution is still "only theory, not fact," evolution is "survival of the fittest," or "it is about how we descend from apes." Creationists know exactly how it works and how to use socio-techniques to manipulate human minds. There are still too many of us scientists (not only in Poland) who do not understand that the battlefield in this controversy is neither the laboratory nor peer-reviewed papers but society's mindset, feelings, and beliefs.

This situation may be compared to the evolutionary process resulting from coexistence. In the U.S., both scientists and creationists have long existed (and evolved) together. Now the movement is emerging in Poland, pitting well-trained creationists against scientists, who are almost completely defenseless against creationists' opinion-making activity.

If Polish scientists do not start to popularize their research, disciplines, and ideas, we will be facing the problem of creationism ever more frequently. The aim is not to convince the creationists to accept evolution, which seems impossible, but to protect younger generations from the creationism mousetrap and to rebuild a positive view of 
science, presently being undermined by such pseudoscientific activity.

\section{Some Challenges to Evolutionists}

As mentioned before, many scientists do not appreciate the growing importance of the creationistic movement. The reasons may be simple - they do not know that creationists did not become extinct, that Maciej Giertych is not a "living fossil" and that we are facing their renaissance; or they think of creationists as of bunch of crazy men who can't read and constitute only a tiny margin of society, and do not realize how well organized they are. An example of such an attitude is one of my department colleagues, who was deeply surprised when presented only a few of the many Polish-language-based websites, books, and journal produced by Polish creationists (he said exactly, "I didn't know it went so far"). Thus it is important to inform our colleagues that the problem of creationism is still alive and that creationist activity may exert a strong, negative impact on education, science, and other aspects of society life.

Creationists are very well organized, devoted to the idea of destroying evolution, and usually cooperative with each other in their battle against "the universal enemy"evolution. They are becoming a worldwide problem for science education, politics, and many other areas of everyday activity. Although their strategies are roughly universal, scientists almost always start to act independently from their colleagues from other countries already experienced in the problem. In effect, we usually start to build our own anti-creationist strategy starting from zero rather than acting more internationally. This is strange because international cooperation is a norm among scientists. For example, we can work on the hominid evolution, protein function, or tetrapod origin in teams, uniting scientists from different countries, but when it comes to dealing with the creationist "wedge strategy," we are in the habit of working alone. The development of an international network and the activation of scientists to work together might be very important and helpful in dealing with creationism. The first step is already done: there is an international peerreviewed journal (Evolution: Education and Outreach) which may used as a platform uniting scientists. But foremost scientists must appreciate that creationists are real; they impose a threat to science and education, that demands we scientists consider their political aspiration and its consequences.

Acknowledgments Maria Ogielska and the anonymous reviewers provided valuable comments to the earlier version of this paper. I thank Joanna Browarska-Borczyk and Billy Tsang for linguistic improvement to the text.
Open Access This article is distributed under the terms of the Creative Commons Attribution Noncommercial License which permits any noncommercial use, distribution, and reproduction in any medium, provided the original author(s) and source are credited.

\section{References}

Anckberg J, Weldon J. Fakty w sporze: stworzenie czy ewolucja. Megas: Warszawa; 2003. (in polish) [The facts on creation vs. evolution].

Behe M. Czarna skrzynka Darwina: biochemiczne wyzwanie dla ewolucjonizmu. Megas: Warszawa; 2008. (in Polish) [Darwin's Black Box: The biochemical challenge to evolution].

Bylica P. Testowalność teorii inteligentnego projektu. Filoz Nauki. 2003;11:41-9. (in Polish) [Falsificability of intelligent design theory].

Cuberbiller M. Kreacjonizm a teoria inteligentnego projektu. Idź pod Prac. 2007;11/40:9. (in Polish) [Creationism and the intelligent design theory].

Dennett D. Darwin's dangerous idea: evolution and the meanings of life. Penguin Books; 1996.

Forrest BC, Gross PR. Biochemistry by design. Trends Biochem Sci. 2007a:32:301-10.

Forrest BC, Gross PR. Creationism's Trojan Horse. The Wedge of Intelligent Design. Oxford University Press; $2007 \mathrm{~b}$.

Fuller S. Nauka vs. Religia. Zysk i-ska. (in Polish) [Science v. Religion. Intelligent design and the problem of evolution]; 2010.

Gadziński M. Rycerze kontrewolucji. Spór o Darwina w Ameryce. Gazeta Wyborcza-Duży Format, 10. 31. (in Polish) [The knights of counterevolution. A dispute about Darwin in America]; 2006.

Gazeta Wyborcza. List otwarty naukowców polskich do Premiera RP pana Jarosława Kaczyńskiego. Gazeta Wyborcza; 11.03 (in Polish) [An open letter to Jaroslaw Kaczyński, the Prime Minister of Republic of Poland); 2006.

Giertych M. Creationism, evolution: nothing has been proved. Nature. 2006;444:265.

Giertych M. O ewolucji w szkołach europejskich. Krzeszowice: Ostoja; 2008. (in Polish) [On the Evolution in the European Parliament].

Graebsch A. Polish scientists fight creationism. Nature. 2006; 443:890-1. doi: $10.1038 / 443890 \mathrm{c}$.

House HW. Inteligentny Projekt 101. Wista. (in Polish) [Intelligent Design 101: Leading Experts Explain the Key Issues]; 2009.

Jaroszyński P, Tarasiewicz P, Chłodna I, Smoleń-Wawrzusin M, editors. Ewolucjonizm czy Kreacjonizm. Fundacja "Lubelska Szkoła Filozofii Chrześcijańskiej” Lublin. (in Polish, English Summary) [Evolutionism or Creationism]; 2008.

Jodkowski K. Wstęp. In: Jodkowski K, editor. Teoria inteligentnego projektu—nowe rozumienie naukowości? Warszawa: Megas; 2007. p. 5-9. (in Polish) [Introduction in Theory of Intelligent Design-New Understanding of Science?].

Johnson P. Na BezdroŁach Teorii Ewolucji. Michaelinum. (in Polish) [The crumbling theory of evolution]; 1989.

Johnson PE. Sąd nad Darwinem. Vocatio. (in Polish) [Darwin on Trial]; 1997.

Johnson PE. Z Otwartym Umysłem Wobec Darwinizmu. Wista (In Polish) [Defeating Darwinizm by Opening Minds]; 2007.

Kielan-Jaworowska Z. Dewolucja Wydziału Biologii UW. Racjonalista 2006; www.racjonalista.pl/kk.php/t,6947 (page viewed at 2009-11-16) [A Devolution of the Biology Division of University of Warsaw. An open letter to the dean of the Division]; 2009.

Kosmos. Untitled editorial note. Kosmos. 1993;42:71. in Polish. 
Kutschera U. A timely wake-up call as antievolutionists publicize their views. Nature. 2006a;444:679.

Kutschera U. Devolution and dinosaurs: the anti-evolution seminar in the European Parliament. Rep Natl Cent Sci Educ. 2006b;26: $10-1$.

Kutschera U. Creationism in Germany and its possible cause. Evol Educ Outreach. 2008;1:84-6. doi:10.1007/s12052-007-0017-4.

Kuźnicki L, Urbanek A. Zasady Nauki o Ewolucji. Podręcznik Dla Szkół Wyższych. Vol. 1\&2. PWN Warszawa (in Polish) [Principles of evolution. A Texbook for Higher Schools]; 1967.

Kuźnicki L. Ewolucjonizm w Polsce 1883-1959. Kosmos. 2009;58:297-313. (in Polish, English summary) [Evolutionism in Poland in the years 1883-1959].

Łomnicki A. Wprowadzenie. In: Łomnicki A, editor. Opinia o filmie video "Ewolucja: rzeczywistość czy domniemanie". Krakow: Universitas Press; 1994. p. 9-14 [Introduction in Opinion on the Video 'Evolution: Fact or Belief?'].

Markowski M. Łódź: w liceum nie ma miejsca dla ewolucji. Gaz Wybor. 2006;10:18. (in Polish) [Łódź: there is no place for the evolution in the lyceum].

Maryniarczyk A. Dlaczego Kreacjonizm? In: Jaroszyński P, Tarasiewicz P, Chłodna I, Smoleń-Wawrzusin M (eds) Ewolucjonizm czy Kreacjonizm. Fundacja "Lubelska Szkoła Filozofii Chrześcijańskiej" Lublin, pp 41-91. (in Polish, English Summary) [Why Creationism In Evolutionism or Creationism]; 2008.

Matzke N. The evolution of creationist movements. Evol Educ Oureach. 2010;3:145-62. doi:10.007/s12052-010-02333-1.

Miller KR. Only a theory: evolution and the battle for America's soul viking books; 2008.

Miller JD, Scott EC, Okamoto S. Public acceptance of evolution. Science. 2006;313:765-6. doi:10.1126/science.1126746.

Moczydłowski E, editor. Pan Bóg czy dobór naturalny. Megas (in Polish) [God or natural selection); 1994.

Nauka Polska. Wykładowcy o teorii ewolucji. http://www.naukawpolsce.pap.pl/nauka/index.jsp?place $=$ Lead07\&news_ca$\mathrm{t} \_\mathrm{id}=148 \&$ news_id $=13719 \&$ layout $=6 \&$ forum_id $=5558 \&$ page $=$ text (in Polish) [Science lectors on the theory of evolution]; 2006.

Numbers RL. The creationists. From scientific creationism to intelligent design. Expanded edition. Harvard University Press; 2006.

Okrój I. Polacy i Religia. http://egospodarka.pl/article/articleprint/ 14902/-1/39 (in Polish) (Poles and Religion); 2006.

Olender M. Amerykańska wojna z Darwinem. Gazeta Wyborcza. 12, 07. (in Polish) [An American war against Darwin]; 2006.

Ostrowski M. Przestraszyli się, czyli naukowa prawda groźna dla mas. www.creationism.org.pl 2009; www.creationism.org.pl/nauka nie dla mas (page viewed on 2009-11-21) [They are afraid, or scientific truth threatening]; 2009.

Pajewski M. Stworzenie czy ewolucja. Wydawnictwo Duch Czasów. Bielsko-Biała. (in Polish) [Creation or evolution]; 1992.

Pezda A. Wiceminister edukacji: poradzimy sobie bez tolerancji. Wywiad z mirosławem orzechowskim. Gaz Wybor. 2006;10:14. (in Polish) [Vice-minister of education: We can do it without the toleration. An interview with Miroslaw Orzechowski].

Pigliucci M. Denying evolution: creation, scientism, and nature of science. Sinauer Associates; 2002.
Podgórska J. Raport: wierz boś nie zwierz. Lekcje religii po polsku. Polityka. 2008;2680:44-9. (in Polish) [Rapport: Believe 'cause you 're not a beast. Religion classes in a Polish way].

Polish Anti-Macroevolution Society. Dewolucja kontra ewolucja. Debata na Wydziale Biologii Uniwersytetu Warszawskiego. www. creationism.org.p12009; creationism.org.p1/dewolucja_kontra ewolucja (page viewed on 2009-11-16) [Devolution vs. evolution. A Debate hosted by Biology Division of University of Warsaw]; 2009.

Sabath K. Na bezdrożach kreacjonizmu naukowego. Kosmos. 1990;40:153-63. (in Polish) [On the pathless tracts of the scientific creationism].

Sabath K. Jak zostałem fundamentalista antyreligijnym. Kosmos. 1993;42:687-714. (in Polish) [How did I became an antireligious fundamentalist].

Sagan D. Spór o naukowość współczesnej teorii inteligentnego projektu na przykładzie Michaela Behe'ego koncepcji nieredukowalnej złożoności. Prz Filoz Nowa Ser. 2004;13:37-54 (in Polish, English Summary) [Does the theory of Intelligent Design meet scientific standards?).

Sagan D. Spór o Nieredeukowalną Złożoność Układów Biochemicznych. Biblioteka Filozoficznych Aspektów Genezy 5. Megas (in Polish) [On the Irreducibly Complex of Biochemical Structures]; 2008.

Sagan D. Ewaluacja ewolucjonistycznych rozwiązań problemu nieredukowalnej złożoności. Otwarte Referatorium Filozoficzne. 2009;2:89-116. (in Polish) [Evaluation of evolutionistic approach to irreducible complexity].

Stelmach A. Człowiek-wynik ślepego przypadku czy zamysłu Bożego? www.piotrskarga.pl/ps,210,5,0,1,I,informacje.html (in Polish) [The man - a result of a blind chance or God's plan?]; 2006.

Strobel L. Dochodzenie w sprawie stwórcy. Dziennikarz bada dowody naukowe przemawiające za istnieniem Boga. Credo. (in Polish) [The case for a creator: Journalist investigates scientific evidence that point toward god]; 2007.

TNS OBOB. Ewolucja po polsku. (in Polish). [Evolution in Polish Way]; 2006.

Tyrała R. Dwa bieguny ewolucjonizmu. Nauka i religia w poznawczym wyścigu zbrojeń. Nomos Press. (in Polish) [Two sides of evolutionism. Science and religion in the cognitive arm race]; 2007.

Watchtower. Jak powstało życie. Przez ewolucję czy przez stwarzanie. Watchtower. (in Polish) [Life-How did it get here? By evolution or by creation?]; 1989.

Wells J. Ikony Ewolucji. W WyŁomie. (in Polish) [Ikons of evolution. Science or myth? Why much of what we teach about evolution is wrong]; 2007.

Wieland C. Kamienie i kości. Mocne dowody przeciwko ewolucji. Na Początku..., 1-2: 12-38 (in Polish) [Stones and Bones. Powerful evidence against evolution]; 2000.

West JG. Intelligent design and creationism just aren't the same. http:// www.discovery.org/a/1329. 2002. (page viewed on 2009-10-12).

Życiński J. Bóg i Ewolucja. Podstawowe Pytania Ewolucjonizmu Chrześcijańskiego. Towarzystwo Naukowe KUL (in polish) [God and Evolution. Basic Questions of Christian Evolutionism]; 2002 . 